\title{
Jean Lambert, Gide familier
}

\section{Emanuele Kanceff}

\section{(2) OpenEdition}

\section{Journals}

\section{Edizione digitale}

URL: http://journals.openedition.org/studifrancesi/36596

DOI: 10.4000/studifrancesi.36596

ISSN: 2427-5856

\section{Editore}

Rosenberg \& Sellier

\section{Edizione cartacea}

Data di pubblicazione: 1 juillet 2005

Paginazione: 194

ISSN: 0039-2944

\section{Notizia bibliografica digitale}

Emanuele Kanceff, «Jean Lambert, Gide familier», Studi Francesi [Online], 145 (XLIX | I) | 2005, online dal 30 novembre 2015, consultato il 18 avril 2021. URL: http://journals.openedition.org/studifrancesi/ 36596 ; DOI: https://doi.org/10.4000/studifrancesi.36596

\section{Questo documento è stato generato automaticamente il 18 avril 2021.}

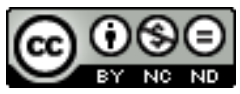

Studi Francesi è distribuita con Licenza Creative Commons Attribuzione - Non commerciale - Non opere derivate 4.0 Internazionale. 


\section{Jean Lambert, Gide familier}

\section{Emanuele Kanceff}

\section{NOTIZIA}

JEAN LAMBERT, Gide familier, nouvelle édition revue, augmentée de lettres inédites, Lyon, Presses Universitaires de Lyon, 2000, pp. 213.

1 Segnaliamo questa riedizione postuma della celebre opera di Jean Lambert, professore all'Università di Southempton, amico di Gide, fondatore della associazione internazionale dedicata allo scrittore, morto nel 1999. Nel presente volume non si trova nessuna allusione né all'autore, né all'edizione originale, del 1198, che è stata riveduta e integrata con la corrispondenza che seguì la pubblicazione della prima edizione. 